\title{
PRANATA SOSIAL DALAM PERTANIAN: STUDI TENTANG PENGETAHUAN LOKAL PADA MASYARAKAT PETANI DI JAWA BARAT
}

\author{
Opan S. Suwartapradja \\ Jurusan Antropologi dan Prodi Sosiologi \\ Program Pasca sarjana Fakultas Ilmu Sosial dan Ilmu Politik \\ Universitas Padjadjaran \\ E-mail : opanss@yahoo.com
}

\begin{abstract}
ABSTRAK. Program Pemerintah dalam peningkatan produksi petanian dimulai dari pemasyarakatan Panca Usaha Tani sejak tahun 1970-an. Hasilnya telah mencapai swasembada beras pada tahun 1984, tetapi masih belum menunjukkan stabilitas keberadaan pangan dan pendapatan petani masih tetap termajinalkan. Hal ini tidak hanya terkait dengan harga jual dan sistem pemasaran yang masih tradisional, akan tetapi juga tingginya biaya produksi. Salah satu upaya dalam mengurangi biaya produksi terutama dibidang ketenaga kerjaan dengan memanfaatkan kearifan lokal, yaitu memanfaatkan suatu bentuk kerja sama dalam kehidupan petani, seperti Liliuran/gropyokan/rempugan. Bentuk kerjasama ini telah melembaga dalam kehidupan mereka, tetapi keberadaannya semakin termarjinalkan. Tulisan ini mendeskripsikan, menggambarkan dan atau melukiskan serta memaknai kearifan lokal sebagai suatu bentuk pranata sosial yang tumbuh dalam kehidupan masyarakat agraris di perdesaan melalui pendekatan kualitatif, yang dapat dipertimbangkan dalam mengaplikasikan program-program pembangunan. Pranata sosial ini merupakan suatu bentuk kerjasama dalam suatu kegiatan yang dilakukan oleh para petani dengan cara bergiliran. Keanggotaannya cukup rasional dan cukup ideal, terkait dengan luasan, pergiliran dan masa tanam, sehingga bagi yang mendapatkan giliran terakhir sesuai dengan jadwal tanam yang serentak dilaksanakan. Dalam bentuk kerjasama ini tidak ada ketentuan yang mengikat dan tidak ada kompensasi. Setiap anggota yang terlibat membayarnya dengan jasa atau tenaga sesuai dengan kegiatan yang dilakukannya. Pranata sosial mengandung kepentingan sosial, eknomi dan budaya. Dari segi sosial, dapat menjaga dan meningkatkan ikatan atau hubungan antar kerabat, teman dan tetangga dan dari segi ekonomi dapat mengurangi biaya produksi. Sedangkan dari segi budaya terkait dengan sistem nilai yang berlaku dalam kehidupan masyarakat yang bersangkutan. Bentuk kerjasama ini mempunyai arti penting dalam kehidupan petani, terutama yang masih diricikan oleh sifat-sifat tradisional (Post Traditional).
\end{abstract}

Kata Kunci : Pranata, sosial, sistem produksi 


\title{
SOCIAL INSTITUTION IN AGRICULTURAL: A STUDY ON THE LOCAL KNOWLEDGE IN PEASEANT SOCIETY IN WEST JAVA
}

\begin{abstract}
The Government's program in increasing agricultural products began when the nation-wide campaign of Panca Usaha Tani (Five Agricultural Efforts) was launched in the 1970's. Although Indonesia claimed to have achieved a state of food independence in 1984, the Panca Usaha Tani program still has not shown any indication of stable food availability until today. Despite the claim, farmers' income is now still insignificant. This condition is related not only to the prevailing traditional sale and marketing system, but also to the high production costs. One of the efforts to reduce production costs, particularly manpower employment, has been to adopt local people, to the adoption of a form of cooperation in farming commonly named Liliuran/Gropyokan/Rempugan. This very form of cooperation has for long been institutionalized, but its existence has been severely marginalized. This article attempts to describe, portray, illustrate and signify this particular local people as a sosial institution that has grown in the life of some rural agrarian societies. Using the qualitative method, the research attempts to come up with results that can be considered and applied in many other development programs. Liliuran/Gropyokan/Rempugan is a form of cooperation in which farmers take turn to perform agricultural activities. The membership is normatively rational and ideal, based on the area, turn rotation and planting cycle. Thus, the last turn coincides with the next cycle's planting season, also organized synchronously. There are no rules and compensation that apply in this type of joint work. Each farmer involved is paid according to the service or work (s)he has performed. A social institution carries in it social, economic and cultural interests. From the social point of view, it can preserve and strengthen the bonds or relations among relatives, friends and, more generally, people in the neighborhood. From the economic point of view, it can reduce production costs. From cultural point of view, it is closely connected to the system of values prevalent in the society in question. This form of cooperation has an important meaning in the life of farmers, particularly those who are still characterized by traditional (or post-traditional) traits.
\end{abstract}

Keywords: Institution, Social, production system

\section{PENDAHULUAN}

Manusia tidak bisa tidak terkait dengan lingkungan disekitarnya. Sebagai makhluk sosial, ia berinteraksi, bermasyarakat dan menghasilkan suatu sistem nilai yang berlaku dalam kehidupannya. Sistem nilai tersebut kemudian disosialisasikan baik dalam lingkungan keluarga maupun dilingkungan sekitarnya melalui proses belajar. Sistem nilai yang mengatur tatanan kehidupan masyarakat itu disebut pranata sosial. Koentjaraningrat (1985:164-165) mengkonsepsikan pranata sosial, sebagai suatu sistem norma khusus yang menata suatu rangkaian tindakan 
berpola mantap guna memenuhi suatu keperluan khusus dari manusia dalam kehidupan masyarakat.

Kelakuan berpola tidak terlepas dari 3 wujud kebudayaan, yaitu : i) wujud ideal, ii) wujud kelakuan dan iii) wujud fisik dari kebudayaan (Koentjaraningrat, 1974 : 15). Total kelakuan manusia yang berpola tersebut sesuai dengan fungsifungsi khasnya merupakan perwujudan dari kebutuhan-kebutuhan hidup manusia dalam bermasyarakat. Aktivitas-aktivitas khas dari kelakuan berpola (wujud kedua dari kebudayaan) ialah sistem norma dan tata kelakuannya (wujud pertama dari kebudayaan) dan peralatannya (wujud ketiga dari kebudayaan) ditambah dengan manusia atau personil yang melaksanakan kelakuan berpola. Itulah yang merupakan suatu pranata atau institution.

Sistem nilai yang dianut suatu masyarakat kemudian diwujudkan dalam suatu kegiatan baik untuk kepentingan individual maupun kepentingan kolektif. Kegiatankegiatan yang berpola tersebut dilaksanakan secara berkesinambungan, sehingga merupakan suatu aktivitas-aktivitas yang terlembagakan (Suwartapradja, 2005).

Aktivitas-aktivitas yang berawal dari ide-ide, gagasan-gagasan dan tindakantindakan berpola itu baik secara mikro maupun secara makro dapat menunjang pembangunan (Koentjaraningrat, 1985).

Pengetahuan lokal dalam kaitannya dengan pembangunan menimbulkan persepsi yang berbeda. Disatu pihak beranggapan bahwa pengetahuan lokal tidak menunjang pembangunan. Sebaliknya, yang beranggapan bahwa pengetahuan lokal dapat menunjang pembangunan dan tidak sedikit pembangunan yang berhasil memperhatikan pengetahuan local Koentjaraningrat, 1974). Menanggapi kedua pendapat yang berbeda tersebut, disadari bahwa tidak semua pengetahuan lokal dapat menunjang pembangunan dan sebaliknya teknologi modern tidak selalu menguntungkan.

Pengetahuan lokal yang menunjang pembangunan, seperti : system sengkedan atau terasering yang mengikuti kontur tanah dimaksudkan untuk menampung dan atau menghimpun air pada tanah yang berlereng terutama air hujan. Dari segi ekologis sistem terasering (nyabuk gunung = jawa, ngais gunung = sunda) ini mengurangi air larian (turn over) yang dapat menimbulkan erosi yang tinggi, sehingga juga dikatakan kearifan ekologi (Soemarwoto, 1983 : 89). Contoh lain, yang terkait dengan budaya petani adalah kolam pekarangan. Secara sosiologis dan antropologis kolam pekarangan mengandung pengertian sosial, ekonomi dan budaya. Dari segi sosial dapat meningkatkan dan atau menjaga prestise, dari segi ekonomi dapat menambah pendapatan rumah tangga dan dari segi budaya kolam pekarangan yang juga berfungsi sebagai tempat mandi, cuci, kakus (MCK) umum sebagai sarana untuk bertemu, berkumpul sambil membincangkan sesuatu yang menjadi kebiasaan mereka. Secara ekologis, kolam pekarangan merupakan suatu system daur ulang dengan mata rantai manusia ternak - ikan - tumbuhan (Soemarwoto, 1983 :92). 
Pengetahuan lokal akan termarjinalkan seiring dengan dinamika penduduk dan perubahan sosial yang terjadi dalam masyarakat. Disisi lain, pengetahuan lokal dalam pertanian berpotensi untuk dikembangkan khususnya dalam mengurangi biaya produksi dan atau meningkatkan pendapatan petani, sehingga menarik untuk dikaji. Dari segi akademik dapat memperkaya keilmuan dibidang sosiologi dan antropologi dan bagi penentu kebijakan dapat menjadi tatanan sosial di dalam mengimplementasikan kebijakan, khususnya yang terkait dengan kehidupan masyarakat agraris.

Tulisan ini, mencoba mengangkat dan memaknai pranata sosial pada masyarakat petani sebagai suatu tatanan sosial di dalam mengimplementasikan program-program pembangunan, khususnya dibidang pertanian.

\section{METODE PENELITIAN}

Penelitian ini mengkaji tentang pranata sosial yang tumbuh dan berkembang dalam kehidupan masyarakat petani. Metode dalam penelitian ini metode deskriptif dengan pendekatan kualitatif. Pendekatan kualitatif ini dimaksudkan untuk mendeskripsikan, menggambarkan atau melukiskan tentang pranata sosial yang tumbuh dan berkembang dalam masyarakat petani.

Objek yang diteliti adalah eksistensi liliuran sebagai bentuk paranata sosial pada masyarakat petani. Penelitian dilakukan di daerah dataran rendah dan dataran tinggi. Daerah dataran rendah merepresentasikan petani lahan basah yaitu mengambil kasus Kabupaten Purwakarta, Cianjur, Kabupaten Bandung dan Kabupaten Sumedang dan cuplikan daerah dataran tinggi yang merepresentasikan petani lahan kering yaitu masyarakat Kasepuhan di Kampung Sirna Rasa Desa Cipta Rasa Kecamatan Cisolok Kabupaten Sukabumi.

\section{GOTONG ROYONG, TOLONG MENOLONG DAN KERJABAKTI}

Koentjaraningrat $(1974 ; 1985)$ mengkonsepsikan bahwa gotong royong dan tolong menolong mempunyai pengertian yang sama. Sebetulnya tidak demikian. Gotong royong dan tolong menolong mempunyai pengertian yang berbeda. Seperti dikemukakan Bung Karno gotong royong lebih pada bentuk kerja bakti yaitu mengerjakan suatu pekerjaan untuk kepentingan bersama (dalam Marzali, 2005). Gotong royong seperti disajikan pada gambar 1, terbagi ke dalam dua bentuk kegiatan, yaitu tolong menolong dan kerja bakti.

Tolong menolong lebih merujuk kepada kepentingan sendiri dan bisa dilakukan secara individual maupun secara kolektif. Bentuk-bentuk tolong menolong bisa terkait dengan bidang pertanian, perbaikan rumah seseorang yang kurang mampu, kepanitiaan pada kegiatan kenduri atau hajatan dan pada orang yang meninggal dan atau terkena bencana. Tolong menolong dibidang pertanian misalnya, dalam bentuk sistem pengerahan tenaga kerja dalam pengolahan lahan, penanaman dan penanaman yang memerlukan tenaga kerja tambahan dari luar anggota keluarga. Sistem ini dimaksudkan untuk mengisi kekurangan tenaga kerja pada masa-masa sibuk dalam lingkaran aktivitas produksi bercocok tanam di 
sawah. Kerjasama seperti ini tidak ada kompensasi, tetapi dilakukan dengan balas jasa. Jadi tolong menolong suatu bentuk kegiatan yang dilakukan secara kolektif atau secara individual bukan untuk kepentingan bersama, melainkan untuk kepentingan perseorangan. Pada bidang papan, misalnya perbaikan atau membangunkan rumah bagi orang kurang mampu atau orang usia lanjut.

Kerja bakti pada awal perkembangannya tumbuh dan berkembang dari masyarakat yaitu merupakan suatu curahan tenaga kerja dari warga masyarakat dalam melakukan pekerjaan tertentu. Bentuk kerja bakti ini kemudian berkembang menjadi swadaya masyarakat, karena dalam mewujudkannya tidak hanya memerlukan tenaga kerja saja, akan tetapi juga memerlukan material dan biaya. Perwujudan dari kegiatan tersebut kemudian muncul istilah urunan dari warga masyarakat, yang dimulai dari urunan dalam bentuk material, seperti urunan bambu untuk perbaikan saluran irigasi, tanggul atau untuk bendung air (dawuan) irigasi sawah-sawah mereka.

Bentuk kerjasama di atas dalam perkembangannya mengalami pergeseran dan untuk memotivasi agar bentuk kerjasama dalam pembangunan tetap berkesinambungan kemudian muncul subsidi dari pemerintah yang diawali pada tahun 1970-an. Subsidi ini dimaksudkan untuk memotivasi masyarakat dan membantu beban masyarakat, terutama golongan miskin, agar tetap berpartisipasi dalam pembangunan.

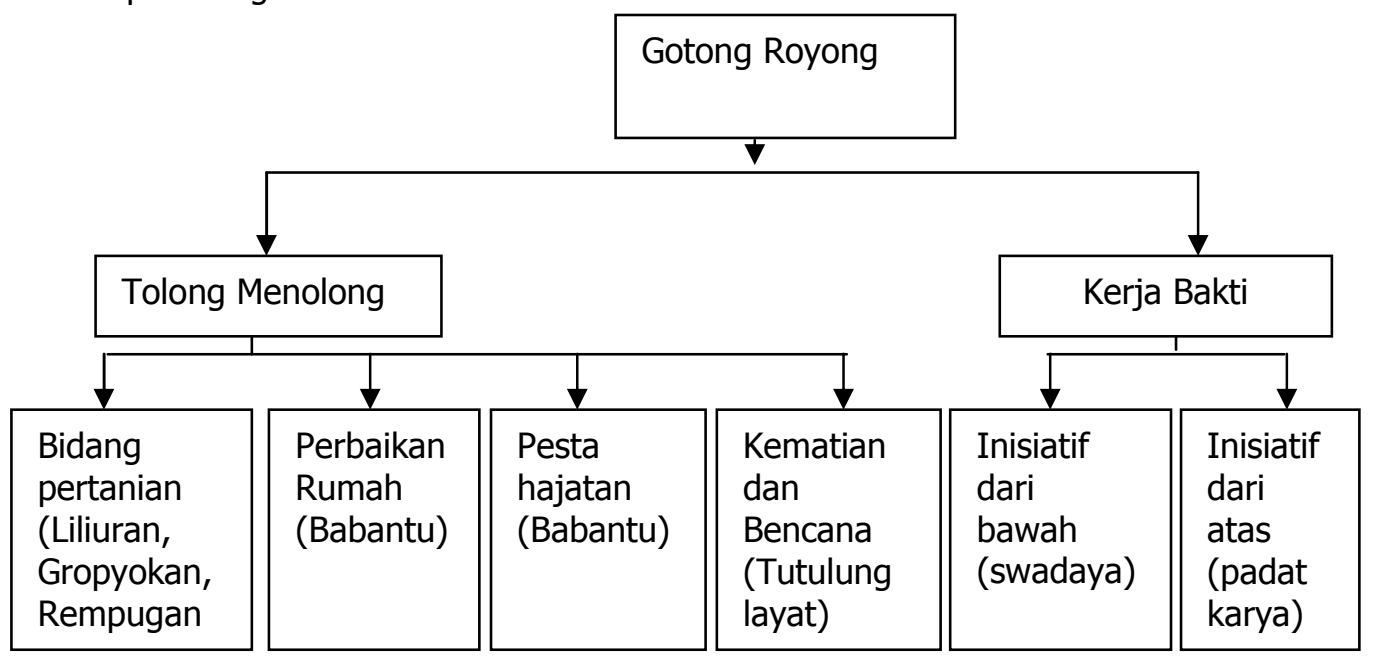

Gambar 1. Taksonomi Gotong royong

\section{LILIURAN DALAM PERTANIAN}

Penduduk yang bertani dilahan basah (Sawah) dan di lahan kering (Tegalan) merupakan dua komunitas yang mempunyai budaya yang berbeda, sekalipun dalam etnis yang sama. Kedua komuniti tersebut sekalipun dalam rumpun bahasa yang sama dapat saja menggunakan kata yang berbeda, tetapi mempunyai arti 
yang sama dan diketahui oleh kedua komunitas tersebut. Perbedaan penggunaan istilah dalam bentuk kerjasama, penduduk yang bertani di lahan basah mempergunakan istilah Liliuran, Gropyokan dan pada masyarakat yang bertani di lahan kering mempergunakan istilah Rempugan.

Liliuran berasal dari kata liur yaitu air yang berputar, yang dalam suatu kegiatan, pekerjaan itu dilakukan secara bergiliran atau bergantian dari urutan ke satu ke urutan berikutnya. Gropyokan, berasal dari kata koroyok yang artinya mengerjakan suatu pekerjaan secara bersama-sama untuk kepentingan orang tertentu. Rempugan berasal dari kata rempug yang artinya bersama-sama, yaitu mengerjakan suatu kegiatan secara bersama-sama. Liliuran, Gropyokan atau Rempugan ketiganya adalah bahasa Sunda yang mempunyai arti yang sama yaitu suatu bentuk kerja sama untuk kepentingan individual. Dalam bahasa Jawa disebut sambatan, dalam bahasa Maluku disebut Pola Gondong, dalam bahasa Menado disebut Mapalus (Suwartapradja, 2004).

Aktivitas yang dilakukan dalam kegiatan Liliuran, Gropyokan atau Rempugan disektor pertanian yang terkait dengan pengolahan lahan, penanaman maupun penyiangan diwujudkan dalam suatu bentuk curahan tenaga kerja dengan cara bergiliran. Ketentuannya merupakan kesepakatan bersama dan tidak ada kompensasi serta setiap peserta yang mendapatkan giliran membalasnya dengan jasa. Begitu seterusnya dilakukan secara bergiliran diantara anggota peserta.

Liliuran sebagai suatu pranata, berawal dari suatu sistem curahan tenaga kerja keluarga yaitu ayah, istri dan anak yang sudah dewasa. Tenaga kerja anak dalam keluarga tersebut kemudian berkurang seiring dengan perubahan marital statusnya, sehingga memerlukan tenaga kerja pengganti. Tenaga kerja buruh tani sebagai pengganti anak meningkatkan biaya produksi, sehingga bagi petani golongan menengah ke bawah atau petani gurem lebih memilih pertemanan. Pertimbangannya adalah efisiensi dan penghematan biaya produksi terutama upah tenaga kerja, merupakan suatu motivasi dalam mewujudkan suatu ide diantara mereka melalui suatu bentuk pertemanan dalam pengolahan lahan.

Pelaku liliuran adalah petani yang memiliki lahan relatif sempit atau dikenal dengan petani gurem yaitu memiliki lahan kurang dari 0,2 ha. Mereka ini memiliki lahan yang lokasinya berbatasan atau berada pada hamparan yang sama. Penggarapan berdasarkan hamparan ini lebih banyak dilakukan oleh petani yang masih mempunyai ikatan kerabat, karena kepemilikan lahan bersumber dari warisan nenek moyang mereka. Sistem liliuran ini juga dilakukan bersama teman/tetangga berdasarkan domisili, tetapi lebih berdasarkan hamparan.

Peserta pada pengolahan lahan basah berkisar 2-3 orang lebih sedikit dari jumlah anggota pengolahan lahan kering, sesuai dengan tingkat kesulitannya. Pada pengolahan lahan kering 2 kali lipat yaitu berkisar 5-10 orang. Jumlah anggota pada kedua sistem pertanian tersebut merupakan suatu pertimbangan yang rasional, erat terkait dengan ketersediaan air, kemampuan dan jadwal tanam. Di lahan basah misalnya, jika keanggotaannya 5-10 orang seperti yang dilakukan di lahan kering, bagi anggota yang mendapat giliran terakhir akan ketinggalan 
menanam yang pada gilirannya pemanenannyapun akan tertinggal dari yang lainnya. Dampak psikologis ketertinggalan penanaman adalah merasa malu dan menjadi sumber munculnya hama penyakit, sehingga mendapat celaan dari teman tetangganya.

Secara formal tidak ada ketentuan yang mengikat mengenai keharusan untuk melakukan kegiatan liliuran/gropyokan/rempugan tersebut. Begitupula dalam perencanaannya. Ide kebersamaan ini termotivasi dari ide beberapa (2-3) orang petani secara non-formal yang dilakukan di lokasi (sawah, tegalan), baik pada saat kunjungan maupun pada saat melakukan aktivitas pertanian. Terwujudnya kegiatan ini juga terjadi ketika sedang berbincang-bincang (Ngobrol) secara mengelompok (Ngariung) di daerah tempat tinggalnya yang menjadi kebiasaan mereka pada sore hari.

Pembicaraan, terkait dengan pengalamannya masing-masing, yang umumnya terkait dengan kesulitan dan atau ketersediaan sarana produksi (Saprodi) dan harga produksi. Seperti, bibit, pupuk, festisida, kesulitan tenaga kerja dan upah buruh tani. Kesulitan tenaga kerja dan tingginya upah buruh tani serta kinerja buruh tani yang kurang setimpal dengan upah yang diberikannya, menjadi pertimbangan utama dalam mewujudkan bentuk liliuran. Kesepakatan liliuran ini kemudian berlanjut pada teknis pelaksanaannya, yaitu dalam menentukan urutan penggarapan. Yang terakhir ini tidak hanya berimplikasi terhadap kemudahan atau mempercepat penyelesaian pekerjaan, akan tetapi juga terhadap teknis lainnya. Ketersediaan air pada lahan yang akan digarap pertama kali yang dikategorikan siap untuk dikerjakan menjadi pertimbangan utama dalam menentukan urutannya. Penentuan urutan ini penting karena terkait dengan kemudahan pengolahan dan teknis lainnya. Seperti, penyediaan makanan yang sebetulnya tidak ada keharusan, tetapi rasa tanggung jawab moral dan menghargai jasa dalam menjaga hubungan dan kebersamaan.

Proses pengolahan lahan yang dimulai dari mencangkul sampai dengan penanaman, berbeda antara lahan basah dan lahan kering dan alat yang dipergunakannyapun menunjukkan perbedaan. Pada pengolahan lahan basah alat yang dipergunakan tidak begitu variatif, sedangkan pada lahan kering lebih variatif karena tingkat kesulitannya lebih tinggi. Begitupula dalam teknik pengolahannya menunjukkan perbedaan. Tahapan kegiatan di lahan kering, seperti juga yang dilakukan pada masyarakat Baduy (Iskandar, 1992; 2001) relatif sama dengan tahapan kegiatan pengolahan lahan kering pada masyarakat kasepuhan di Sirnarasa (Adimihardja, 1992). Oleh karena itu curahan hari orang kerja (HOK) akan berbeda dan biaya yang dikeluarkannya akan berbeda pula. Curahan HOK pada pengolahan lahan kering dua kali lipat dari pengolahan lahan basah. 


\section{TOLONG MENOLONG}

Sistem bantu membantu yang berlaku pada masyarakat agraris mengandung sistem nilai dan azas kekeluargaan diantara anggota pelaku kegiatan. Kekeluargaan dalam hal ini adalah menjalin dan atau mengeratkan hubungan, hidup bersama, merasakan kehidupan senasib sepenanggungan sama rata sama rasa atau berdiri sama tinggi duduk sama rendah. Sistem nilai ini kemudian dilembagakan oleh pemerintah melalui Undang-Undang Dasar 1945 pasal 33 ayat 1. Pemerintah dalam hal ini mengkonsepsikan suatu bentuk kekeluargaan yang dituangkan dalam Pasal 33 ini khususnya dalam konsep Ekonomi Pancasila (Hatta, 1946; 1963; Mubiyarto, 1983; Budiman, 1989; Wilopo, 1985; Widjoyo Nitisasatro, 1985, dalam Marzali, 2005 :163-164). Pengertian tolong menolong berbeda dengan gotong royong. Tolong menolong untuk kepentingan individual, sedangkan gorong royong untuk kepentingan kolektif. Namun, kedua kegiatan tersebut menguatkan hubungan kekeluargaan yang mencerminkan kehidupan kebersamaan diantara pelakunya. Jadi, tolong menolong sebetulnya lebih menekankan kepada suatu bentuk hubungan antar manusia (Human Relationship). Seperti, bantuan terhadap teman, tetangga yang dilanda bencana alam dan menolong mereka yang kekurangan makanan dan membantu menjadi panitia dalam pesta/kenduri. Dibidang pertanian, seorang petani membantu/menolong teman, tetangga yang tertinggal pengolahan lahannya.

\section{SWADAYA DAN PADAT KARYA}

Penghimpunan material dan atau biaya dalam suatu kegiatan atas kesukarelaan warga masyarakat yang diawali dari orang kaya pemilik lahan luas. Kesadaran orang-orang kaya tersebut kemudian diikuti oleh warga masyarakat lainnya, sehingga secara informal terhimpun sejumlah dana untuk mewujudkan suatu kegiatan. Sistem ini kemudian di formalkan dalam rapat desa, sehingga muncul istilah urunan desa (Urdes). Seperti, urdes untuk pembangunan atau perbaikan jalan desa, irigasi, pembangunan sekolah dasar (SD), pembangunan mesjid dan pembangunan kantor desa. Secara formal besaran urdes yang membedakan antar anggota masyarakat ini mengacu kepada strata sosial masyarakat berdasarkan luas kepemilikan lahan dengan perbandingan $3: 2: 1$. Artinya, orang kaya berkewajiban membayar 3 bagian atau 3 kali lebih besar dari ketentuan yang harus dibayar oleh orang miskin dan golongan menengah 2 kali lebih besar dari golongan miskin (Suwartapradja, 2009). Ketentuan-ketentuan tersebut diputuskan dalam rapat desa yang dilakukan di akhir tahun bersamaan dengan penyusunan anggaran pembangunan dan belanja desa (APBD) tahun berikutnya, sehingga pembangunan yang dilaksanakan disebut swadaya masyarakat. 
Pada era reformasi yang dibarengi dengan krisis multidimensional kegiatan kerja bakti digiatkan kembali dengan maksud membantu pendapatan penduduk golongan miskin. Mereka bekerja untuk kepentingan umum, tetapi mendapatkan upah yang dinamakan padat karya (Adiwilaga, 1976; Kartasasmita, 1998). Secara singkat padat karya dikonsepsikan sebagai suatu bentuk pengerahan tenaga kerja untuk mengerjakan suatu pekerjaan bagi kepentingan umum yang setiap pekerjanya mendapat upah yang bersumber dari subsidi pemerintah top down.

\section{IMPLIKASI TERHADAP SOSIAL, EKONOMI DAN BUDAYA}

Upaya dalam mengentaskan kemiskinan dan atau meningkatkan kesejahteraan rakyat telah mengalami pergeseran karena adanya perubahan struktur sosial, baik pada penduduk yang terkena pembangunan maupun yang tidak terkena pembangunan. Bagi penduduk yang terkena pembangunan, seperti pembangunan perumahan, industri, kesehatan dan pembangunan bendungan mengharuskannya untuk pindah, sehingga akan terjadi dinamika perubahan ditempatnya yang baru. Seperti, beralihnya pekerjaan dari sektor pertanian ke sektor non-pertanian dan meningkatnya mobilitas penduduk, karena sektor pertanian sudah tidak menunjang lagi. Fenomena ini mengindikasikan bahwa ikatan kebersamaan cenderung akan semakin longgar, karena tidak lagi berkumpul dengan teman, tetangga dan atau kerabat. Perpindahan berarti pecahnya komunitas dan ini berdampak terhadap ikatan kebersamaan (Ahmad, dkk, 1991; Suwartapradja, 1986). Ini mengandung pengertian bahwa tatanan kehidupan tengah mengalami pergeseran dan atau perubahan, sehingga sistem nilai dan hubungan-hubungan sosial semakin longgar (Lauer, 2003).

Perubahan pekerjaan berdampak terhadap meningkatkan mobilitas penduduk, terutama mobilitas sirkuler dari desa ke kota. Mobilitas sirkuler desa - kota yang terjadi erat terkait dengan aspek ekonomi, yaitu semakin sempitnya lapangan kerja di pedesaan, pendapatan yang rendah dan atau adanya nilai kefaedahan daerah yang berbeda (Mantra, 1981). Fenomena ini telah menimbulkan perubahan sosial dengan masuknya sistem nilai dan budaya perkotaan yang dibawanya ke daerah asalnya, sehingga menjadi "jembatan" transformasi budaya ke daerah perdesaan (Saefullah, 1995, 2000, 2008). Mobilitas sirkuler desa-kota dan beralihnya pekerjaan dari sektor pertanian ke sektor non-pertanian, lebih banyak dilakukan oleh gerenasi muda, sehingga berdampak terhadap sistem nilai dan budaya pada masyarakat yang bersangkutan. Fenomena sosial ini telah menimbulkan perubahan sosial yang berdampak terhadap suatu bentuk kerjasama seperti gotong royong dan Liliuran/gropyokan/ rempugan yang semakin longgar.

Liliuran/gropyokan/rempugan sebagai suatu pranata sosial, eksistensinya semakin termarjinalkan. Disatu pihak sistem ini dinilai tidak efektif dan tidak efisien dibandingkan dengan mekanisasi pertanian, yang sebetulnya mekanisasi pertanian itu sendiri tidak selalu menguntungkan. Sebagai contoh, dalam pengolahan lahan dengan menggunakan traktor kedalamannya hanya mencapai sekitar $10 \mathrm{~cm}$ lebih dangkal dibandingkan dengan penggunaan cangkul yang 
mencapai kedalaman sekitar 15 - $20 \mathrm{~cm}$ (sapacul satengah). Pembalikan tanah yang lebih dalam lebih baik, karena tanah semakin gembur, sehingga produksinyapun tidak mengalami penurunan. Sebaliknya, pembalikan tanah yang relatif dangkal, tekstur tanah bagian dalam tidak terangkat dan tetap mengeras, sehingga kesuburan dan kegemburan tanah menurun yang pada gilirannya tingkat produksinyapun rendah. Dari segi praktis traktor lebih efektif dan efisien, akan tetapi pada topografi yang berada pada kemiringan $>15^{\circ}$ hanya dapat dilakukan oleh tenaga manusia.

Liliuran/gropyokan/rempugan adalah suatu bentuk kerjasama bantu membantu sebagai sarana dalam menjaga dan atau mengeratkan hubungan diantara pelakunya. Melalui bentuk kegiatan ini meningkatkan hubungan-hubungan sosial karena mereka dapat saling bertemu, berbincang-bincang atau bersilaturahmi. Interaksi yang terjadi juga dapat menumbuhkembangkan rasa solidaritas, kebersamaan, senasib dan sepenanggungan, sehingga hubungan akan tetap terpelihara. Fenomena tersebut masih kental dalam kehidupan para petani terutama pada mereka yang masih dicirikan oleh sifat-sifat tradisional (Post Traditional). Dari segi ekonomi pranata sosial tersebut nampaknya dapat menguntungkan bagi kedua belah pihak atau antar anggota yang terlibat, tidak ada anggota yang dirugikan dan mempunyai hak dan kewajiban yang sama.

Bentuk jalinan kerjasama ini dilakukan dalam setiap kegiatan, baik disektor pertanian maupun disektor non-pertanian. Disektor pertanian, terutama dilakukan dalam pengolahan lahan, penanaman dan penyiangan. Secara ekonomis sistem ini dapat mengurangi biaya produksi cukup signifikan, sehingga dapat menghemat biaya produksi yang pada gilirannya dapat meningkatkan pendapatan petani. Sebagai contoh, curahan tenaga kerja dalam pengolahan lahan sawah ukuran 1 ha menyerap tenaga kerja sebanyak 86 hari orang kerja (HOK). Upah kerja buruh tani laki-laki dalam pengolahan lahan Rp. 30.000,- tiap orang tiap hari. Ini berarti upah tenaga kerja yang diperlukan sebesar Rp. 2.580.000,- tiap ha atau bagi petani gurem yang memiliki lahan 0,2 ha, harus mengeluarkan biaya produksi sekitar Rp. 516.000,-. Biaya produksi tersebut dapat dihemat melalui bentuk kerja sama liliuran.

Liliuran/gropyokan/rempugan adalah suatu pranata sosial yang tumbuh dan berkembang dari masyarakat dan telah melembaga dalam kehidupan petani. Pranata ini mengandung sistem nilai yaitu menjalin dan memelihara ikatan kebersamaan, solidaritas, norma-norma yang berlaku dan senasib sepenanggungan dalam kehidupan bermasyarakat. Ini berarti pula hubunganhubungan sosial dalam kehidupan mereka tetap terjalin. Dilain fihak, secara teknis sistem ini dapat mengatasi kekurangan tenaga kerja atau mengurangi ketergantungan terhadap buruh tani dan atau mengurangi biaya produksi yang berdampak terhadap sistem produksi dan distribusi. 


\section{SIMPULAN DAN SARAN}

\section{Simpulan}

Konsep gotong royong berbeda dengan tolong menolong seperti dikemukakan Marzali (2005) gotong royong adalah suatu bentuk kerjasama untuk kepentingan bersama dan bukan untuk kepentingan perseorangan. Kerjasama untuk kepentingan individu yang dilakukan secara bergiliran disebut Liliuran/gropyokan/rempugan. Tolong menolong dalam kegiatan pertanian adalah bantu membantu karena lebih menekankan pada suatu pekerjaan yang memerlukan tenaga kerja. Sebaliknya tolong menolong lebih menekankan kepada rangsangan perasaan terhadap seseorang yang sedang ditimpa musibah.

Bentuk kerjasama dalam sistem Liliuran/gropyokan/rempugan merupakan suatu pranata sosial yang mempunyai arti penting dalam kehidupan masyarakat petani. Bentuk kerjasama ini, terkait dengan aspek sosial, ekonomi dan budaya. Dari segi sosial dapat menjaga dan meningkatkan hubunganhubungan sosial dan meningkatkan kebersamaan dalam kehidupan bermasyarakat. Dari aspek ekonomi dapat mengurangi biaya produksi yang pada gilirannya meningkatkan pendapatan petani. Sedangkan dari aspek budaya dapat memelihara nilai-nilai sosial kemasyarakatan. Ketiga aspek tersebut memberikan kontribusi yang berharga tidak hanya dari segi praktis akan tetapi juga dari segi akademis.

\section{Saran}

Sistem nilai yang berlaku dalam masyarakat petani terutama yang dicirikan oleh sifat-sifat tradisonal tidak selalu kurang menguntungkan, akan tetapi juga terdapat nilai-nilai yang dapat menunjang pembangunan. Oleh karena itu, kebijakan-kebijakan yang memperhatikan nilai-nilai yang berlaku dalam masyarakat, akan mendapat apresiasi, dapat menunjang program-program pembangunan, sehingga pembangunan terlanjutkan (Sustainable).

\section{DAFTAR PUSTAKA}

Adimihardja, K. 1992. Kasepuhan yang Tumbuh Diatas yang Luruh, Bandung, Tarsito.

Adiwilaga, A. 1976. Padat Karya, Makalah, Bandung, Pusat Penelitian Kebudayaan Universitas Padjadjaran.

Ahmad, H. \& Suwartapradja, O. S. 1991. Strategi adaptasi Ngalemah Penduduk Akibat Proyek Besar : Dalam Kontek Keterbatasan Sumber DayaLokal, Laporan penelitian, Direktorat Pembinaan Penelitian dan Pengabdian Pada Masyarakat Direktorat Jenderal Pendidikan Tinggi Departemen 
Pendidikan dan kebudayaan Kerjasama dengan Fakultas Ilmu Sosial dan Ilmu Politik Universitas Padjadjaran.

Iskandar, J. 1992. Ekologi Perladagangan di Indonesia, Djambatan.

. 2001. Manusia, Budaya dan Lingkungan, Bandung, Humaniora.

Kartasasmita, G. 1998. Padat karya, Makalah, Seminar Pembangunan di Jawa Barat.

Koentjaraningrat. 1985. Pokok-pokok Antropologi Sosial, Jakarta, Aksara Baru.

Koentjaraningrat. 1974. Kebudayaan, Mentalitet dan Pembangunan, Jakarta, Gramedia.

Lauer, R. H. 2003. Persepektif Tentang Perubahan Sosial, Jakarta, Rineka Cipta.

Marzali, Amri. 2005. Antropologi dan Pembangunan Indonesia, Jakarta, Kencana.

Mantra, Ida Bagus. 1981. Mobilitas Sirkuler Desa - Kota, Yogyakarta, PPK, Universitas Gadjahmada.

Saefullah, A. D. 1995. Mobilitas Penduduk Desa-Kota: Jembatan Modernisasi Pedesaan, Pidato Pengukuhan Jabatan Guru Besar Dalam Ilmu Kependudukan, Departemen Pendidikan dan Kebudayaan, Universitas Padjadjaran, 25 September

2000. Migrasi Sebagai "Jembatan" Desa-Kota, Orasi IImiah, Pengukuhan Guru Besar, Bandung, Universitas Padjadjaran.

. 2008. Modernisasi Perdesaan Dampak Mobilitas Penduduk, Bandung, Truenorth.

Soemarwoto, O. 1983. Ekologi, Pembangunan dan Lingkungan Hidup, Jakarta, Djambatan

Suwartapradja, O. S. 1986. Aspek Sosial dan Budaya dalam Pemantauan Perpindahan Penduduk yang Terkena Proyek PLTA Saguling, Laporan penelitian, PPSDAL, LP-UNPAD

. 2004. Liliuran Suatu Pranara Lokal, Makalah, Seminar Sistem Sosial dan Budaya Indonesia, Program Pasca Sarjana Universitas Padjadjaran, Bandung, Januari. 
2005. Aspek Sosial Budaya dalam Analisis Dampak Lingkungan, Makalah, Kursus Dasar-dasar Analisis Mengenai Dampak Lingkungan, Kerjasama PPSDAL dan Pemerintah Kabupaten Bandung, 25 Mei-8 Juni

. 2009. Strategi Penduduk Dalam Menghadapi Kaetidakapstian Pembangunan Waduk Jatigede di Kabupaten Sumedang, Disertasi, Bandung, Program Pascasarjana Universitas Padjadjaran 